\author{
Selim Daku \\ University of Gjilan "Kadri Zeka", Kosovo \\ Abdulla Azizi \\ South East European University, Macedonia
}

\title{
THE IMPACT OF SOCIAL MEDIA ON THE DEVELOPMENT OF INTERNATIONAL RELATIONS IN WESTERN BALKAN COUNTRIES
}

\author{
UDK: 004.738 .5 (497) \\ Primljeno: 10. III. 2018. \\ Pregledni znanstveni rad
}

\begin{abstract}
Nowadays, the use of social media has grown worldwide, and this has resulted in increased influence on international relations. Other researches show that this form of communication is increasing, so the research goal is to determine the extent of social media impact on the development of international relations in the Western Balkan Countries.

To achieve the results, it was conducted an online survey with experts and representatives of institutions, and through the questionnaire was evaluated the use of social networks, the effects of use, transparency and reliability. The collected data were analyzed carefully, and came to the conclusion that; respondents highly assess the impact of social media on international relations development in Western Balkan countries. The social media have achieved higher effect, also without the influence of international policy leaders, in some areas such as transparency.
\end{abstract}

Key words: Influences, Western Balkans, international relations, social media.

\section{INTRODUCTION}

In Western Balkan Countries, internet and its services are very popular and are used by the majority of the population. The percentage of the population with internet access in Albania is 60.10\%, (Albanian Media Institute, 2015), in Montenegro 69.8\% (Statistical Office of Montenegro, 2016) and in Serbia 51.50\% (Blic, 2017). In Kosovo over $88.8 \%$ of the population use the internet (Kosovo Agency of Statistics, 2018), while in Macedonia 69.4\% of the population has access to the internet (State Statistical Office - RM, 2016).

Because of this high popularity of the internet and its services, it is important to consider the impact that social media has on the practice of inter-ethnic relations developement in Western Balkans Countries. That the social media has given meaning to inter-national relations is understandable, even Western Balkan Countries with high levels of Internet usage cannot be indifferent to these developments. We have seen many times when presidents of different countries exchanged their thoughts 
on Twitter. In 2017, US President Donald Trump commuicated in public with the Mexican President through Twitter, asking him to think about canceling the US visit because Mexico did not undertake border wall costs between the United States and Mexico (Fox News, 2017).

We are seeing this form of communication every day, also it is present at Western Ballkan Countries heads, as was the case communication between the Prime Minister of Albania and Serbia on Twitter because of a decision of sports arbiter court (CAS), that gives three points to Albanian football team after the interruption of the tension game in Belgrade (Lapsi Al, 2015). It is very important to understand this form of communication in order to use it effectively as a means of communication and development of interstate or international relations in Western Balkan Countries. We also need to know what implications it can bring about the practice of developing international relations and the effect that it can have on them.

\section{THE IMPACT OF SOCIAL MEDIA (STATEMENT OF THE PROBLEM)}

In order to develop communication with the public and other relevant institutions, the use of social media from public institutions is increased. The use of social media has brought a situation that has imposed the fast and easy communication between international subjects. Of particular importance to the public is the measurement of social media influence on international relations development in Western Balkan Countries (Kosovo, Albania, Macedonia, Serbia and Montenegro).

The aim of the study is to analyze the impact that social media has on the leaders of responsible institutions for the development of international relations; the implications that social media bring to the development of international relations like the implementation of social media use in public administration and other capacities that they have; the reaction of old Balkan policies to new technology and the relationship of diplomacy with it.

\section{LITERATURE REVIEW}

\subsection{Social media and their impact on the development of international relations}

When we think that social networks obviously remember the social network Facebook, Twitter, Instagram or others. Social media is best understood as a group of new kinds of online media, which share most or all of the following characteristics: Participation, Openness, Conversation, Community, Connectedness 
(Mayfield, 2008). The domestic and global public opinion have become key factors in the formulation of foreign policy in the age of mediation. Before this period, in ternational politics were carried out mostly behind closed doors in secrecy and covert manoeuvrings (McNair, 1998). In Western Balkan Countries have been a large presence of foreign policy behind closed doors, and public opinion often has been exposed by unexpected attitude and actions by the leaders of the states .

As of June 2010, 22\% of time spent online (or one in every four and a half minutes) it is spent using social media and blog sites worldwide ("Social Networks/ Blogs Now Account for One in Every Four and a Half Minutes Online,” 2010), (Sheedy, 2011). This statistic represents the fact that politicians are not indifferent to this situation. Until now, this technology has been advanced by creating other social networks that have increased their impact on the development of inter-state and international relations in the Western Balkans Countries.

With the representation of social media at the beginning of XXI century, foreign diplomats and policy makers face new international communication approaches. Increasing access to the online media world has implications stretching beyond a period of advanced global access, this because the global communication tools are personalized. A side effect is that the "street"-or, public opinion-has become virtually empowered. That is, a foreign public's collective voice can be emailed, posted, tweeted - instantly transmitted - to a global audience that can respond in kind (Clifton, M., \& Jagla, L, 2013). Diplomats should embrace this development technology because it can accelerate the political, social and economic change in the world. They should see this change from the individual's point of view without public responsbility.

Leaders of institutions who develope international reports, personally use the social media to gather general information and not just about their professional field. Search engine marketing was considered the most important, followed by blogs, social networks, video sharing and forums or message boards (Gordon, 2010). For practical reasons, it is good to assemble a team to be responsible for activity in social media (Toivo, 2012). This would increase the coordination and effectiveness of work, where the location would not matter. David Paull Nickles in his work Under the Wire (2003) states that the faster reporting of events, in his analysis, also led to an increase in the power of public opinion and its pressure on politicians during international crises (Nickles, 2003).

\section{THE OUTCOMES OF SOCIAL MEDIA IMPACT IN INTERNATIONAL RELATIONS ON WESTERN BALKANS COUNTRIES}

To see the impact of media on international relations development in Western Balkan Countries, we need to measure some of factors that influence its development, including the main policy developer, media, non-governmental organizations, 
institutes, and relevant experts. The sample used in this research corresponds the aim of the research, and its size is 100 respondents from five Western Balkan Countries, including all institutions. All individuals involved in the research should accomplish these two criteria: To be over 18 years and to belong one of the research category. It was not difficult to find respondents because this category of individuals is accessible and their number that meets the conditions for the survey is not small.

To analyze the impact of social media on international relations development, it was provided a closed questionnaire with anonymous questions, that will give us detailed data about the purpose of the study. The questionnaire is divided into five parts, including: first part - general questions; second part - questions about institutional factors (representatives of institutions); third part - questions representing media community, fourth part - questions representing non-governmental actors (nongovernmental organizations, institutes, relevant experts); final part - closing clauses.

\subsection{Results}

After the preparation of all parts of work, studying and analyzing the purpose of the study, the model, the variables and their operationalization, we gain factors that show the influence of social media on international relations development in Western Balkans Countries. The survey was conducted electronically with representatives of states, media, civil society and field experts in Albania, Kosovo, Macedonia, Serbia and Montenegro. To the question: How you assess the impact of social media on international relations development? - respondents answered as below;

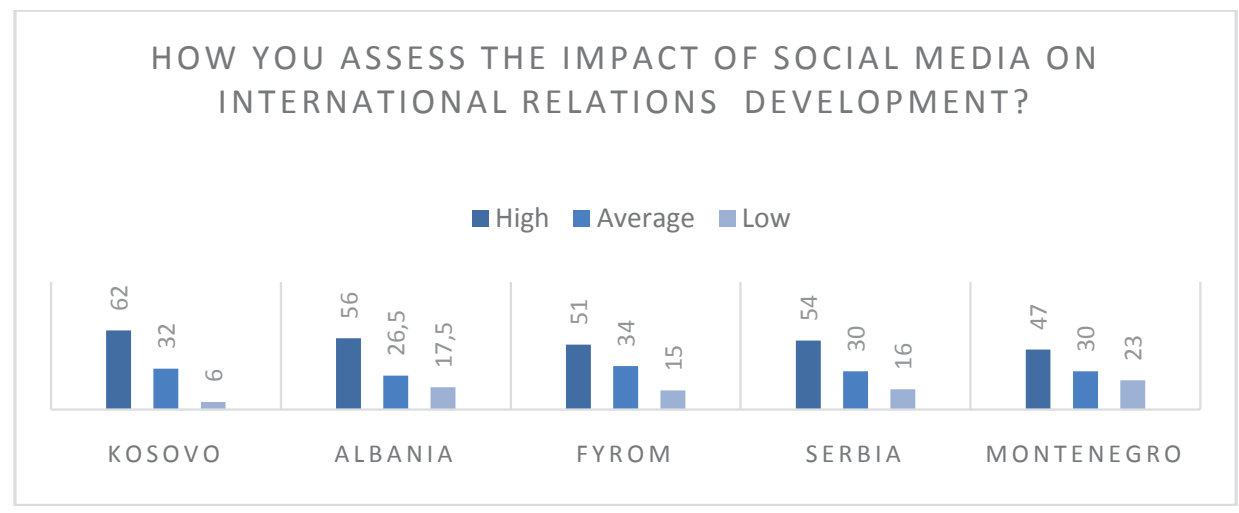

Table 1. The impact of social media on international relations 
From what we see in this table, we estimate that respondents in five states where research has been conducted admit a high impact of social media on international development. The biggest difference is noted in Kosovo where $62 \%$ of respondents think that social media have high impact, while in Montenegro only $47 \%$ of them. A special contribution to the development of the use of social media by institutions have state leaders, as was the case of communication platform via Twitter between Prime Minister of Albania and Serbia on Kosovo issue. That discussion influenced the realization of several other meetings between these countries, to clarify their positions.

On the other question realized with respondents; Should the public employee use social networks for the development of international relations? - they answered that it should be used, with 70\% in Kosovo; it should not be used at $8.5 \%$ in Albania; $37.5 \%$ of respondents in Montenegro consider that state workers may ever use social networks to develop international relations. From this we can appreciate that the social media have become the need to carry out public works and as such they are a necessity of time to work effectively.

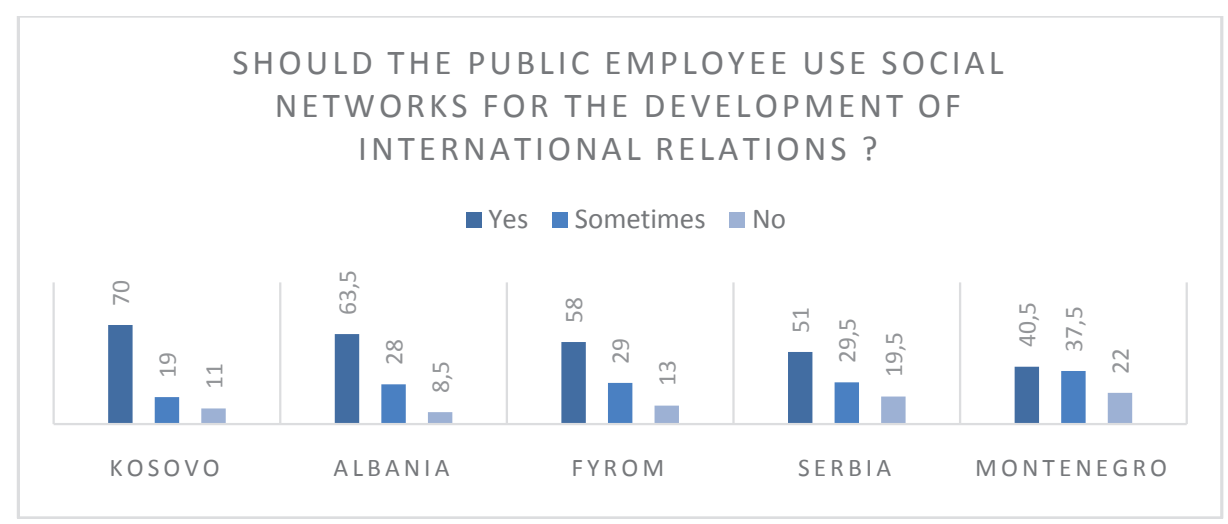

Table 2. Public officials and social media

At the question about the extent of social media influence on changing communication ways of states in developing international relations, the respondents have provided the following answers. 


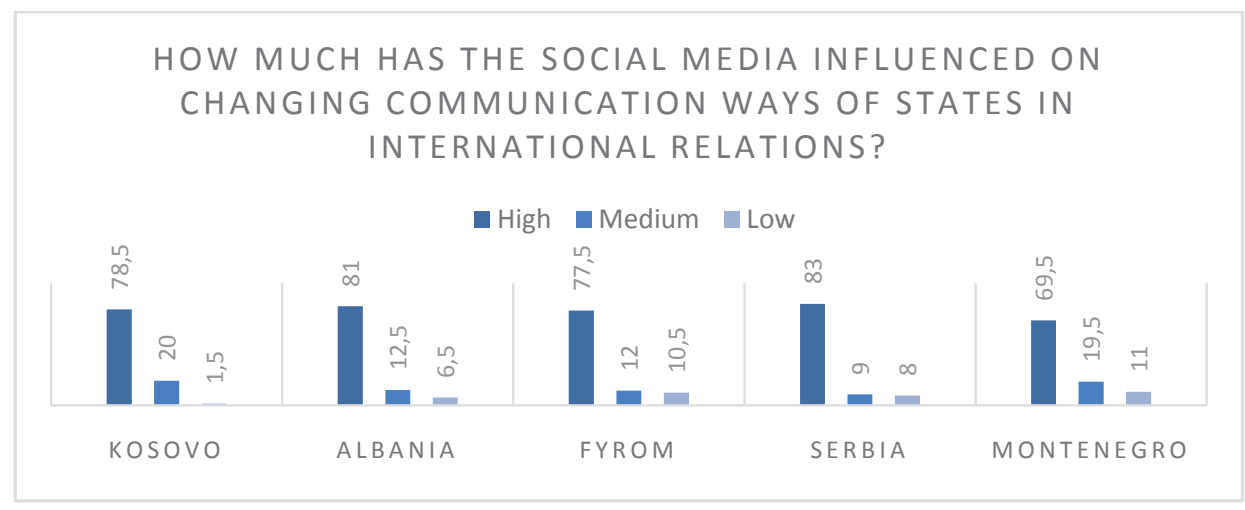

Table 3. The impact of social media on changing the communication ways of states in international relations.

Over $83 \%$ of respondents in Serbia affirm that social networks have an influence on changing state communication ways in international relations, as well as $81 \%$ of respondents in albania think the same. Meanwhile, $20 \%$ of respondents in Kosovo and $19.5 \%$ in Montenegro think that social media have an average impact on changing states communication ways in international relations. Only $11 \%$ of respondents in Montenegro think that social media have a little influence in changing states communication ways in international relations. This implies that the development of international relations in Western Balkan Countries is a part of global developments trend. This implies increased care and public accountability in international relations.

We also analyzed the impact of social media reporting on changing attitudes from public institutions regarding to international relations.

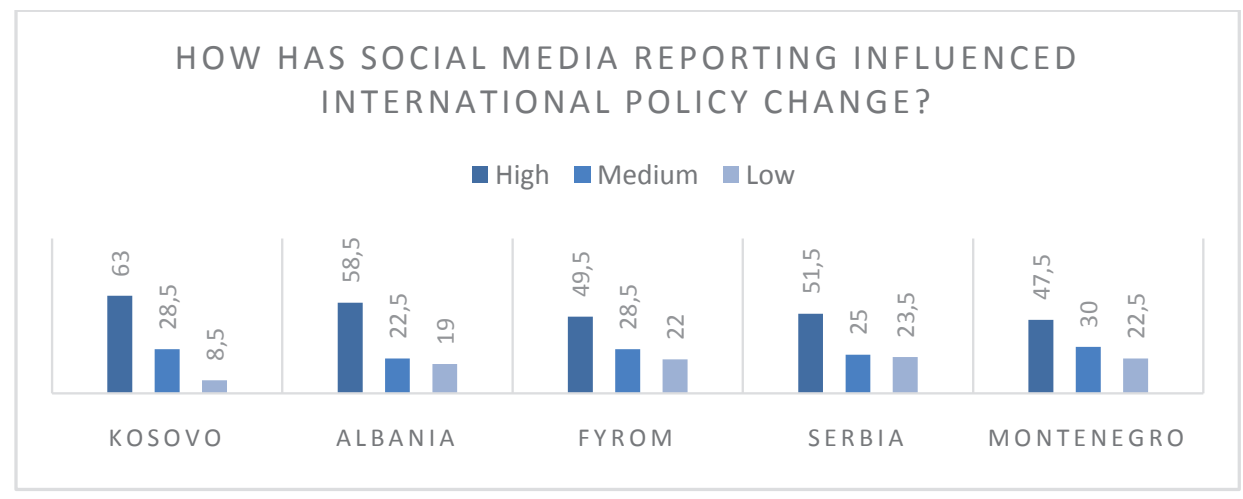

Table 4. Changing international policies from social media reporting to the Western Balkan Countries 
Media reports have a high impact on the orientation of international relations development in the Western Balkan Countries. In Kosovo, 63\% of respondents affirmed that social media reporting has a high impact on changing international state policies, also in Albania 58.5\% of them think the same; 30\% of respondents in Montenegro affirm that media reports have an avarage impact in changing state policies; and in Serbia $23.5 \%$ of respondents think that media reporting have a little impact on changing international state policies. From these data we can conclude that media have a very important role in international policy orientation and as such have a significant influence on in Western Balkan developments. In many cases they can determine international policies.

During the survey we have also analyzed the impact of social media in increasing the transparency of state instutions.

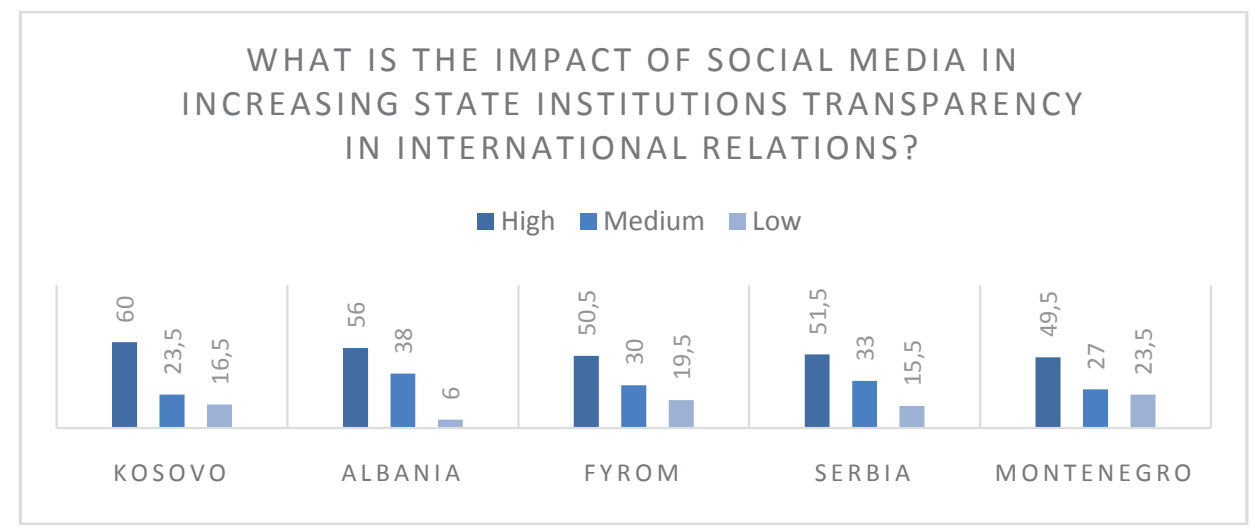

Table5. Social media and transparency of institutions

Social media has influenced in increasing transparency of institutions in international relations development in Western Balkan Countries. In Kosovo 60\% and in Albania 56\% of respondents affirmed a high impact of social media in institutions transparecy, while 38\% of respondents in Albania and 33\% in Serbia consider that social media have an average impact on increasing transparency of international relations institutions.

In Montenegro 23.5\% and in Macedonia (FYROM) $19.5 \%$ of respondents affirmed that the impact of social media on increasing the transparency of institutions is low. In addition to other impacts on the development of international politics in the Western Balkan Countries, social media have also contributed to the enhancement of the institutions transparency of relevant states. This implies that the use of social media by institutions, apart transparency and accountability, also increase decisionmaking of citizens in international activity of the relevant state. 
From the respondents, we have received data on the extent of the impact from social and traditional media on international relations development.

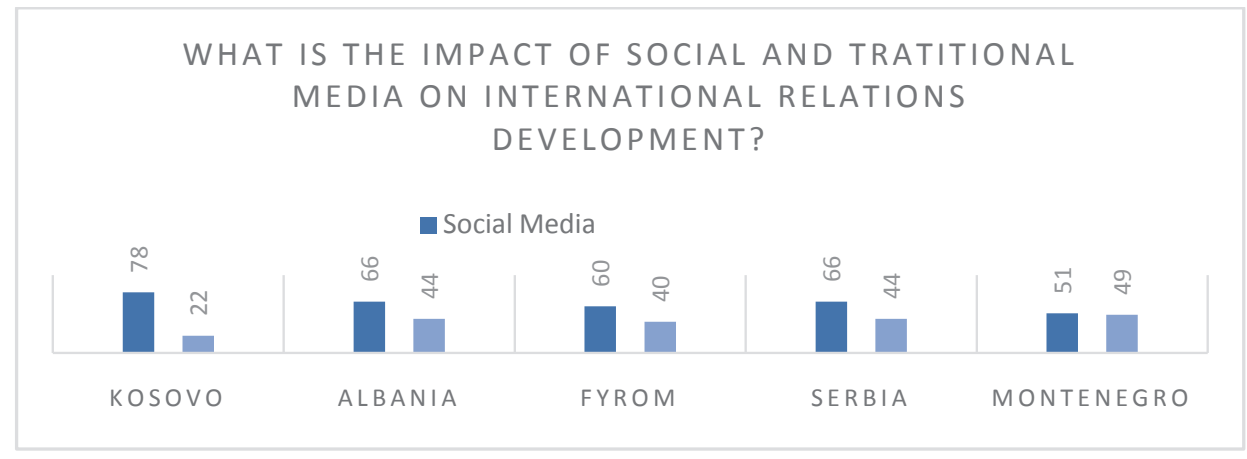

Table 6. Social and traditional media

In Kosovo $78 \%$ in Albania and Serbia $66 \%$ of respondents affirmed that social media have a high impact on international relations development in Western Balkan Countries compared to traditional media, while $49 \%$ in Montenegro and $44 \%$ of respondents in Albania and Serbia think that traditional media have more impact on international relations development. This implies that social media are more advanced than traditional media and as such have a higher impact on international relations development.

Respondents have also answered to the question of the reliability of social media.

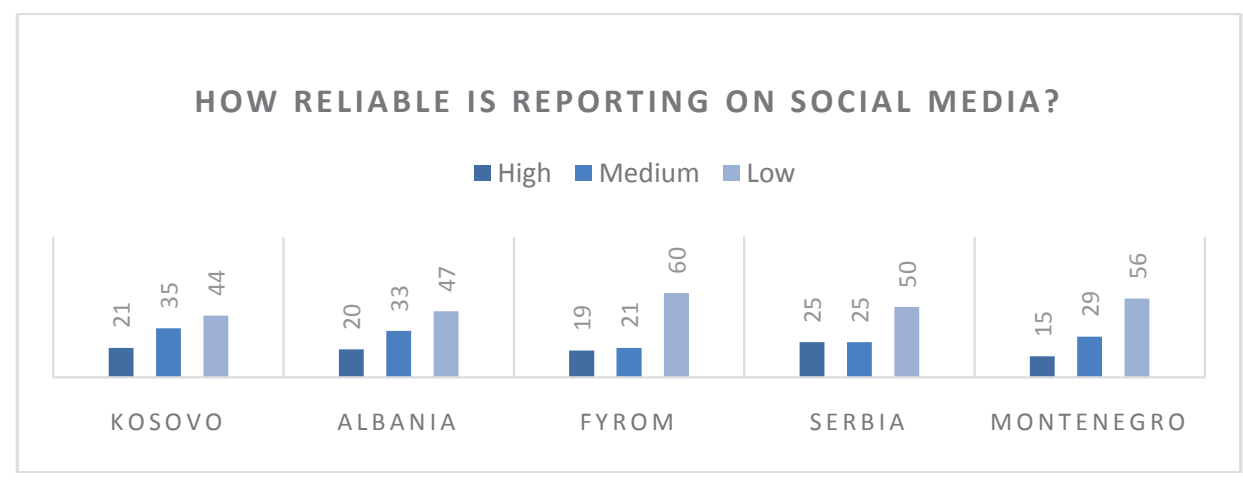

Table 7. Reliability in social media

In Serbia $25 \%$ and in Kosovo $21 \%$ of respondents have high confidence in social media reporting. Meanwhile, 35\% of respondents in Kosovo and 33\% of them in Albania have an avarage confidence in social media. In Macedonia 60\% 
and in Montenegro 56\% of respondents have a low confidence in social media. This implies that, even though social media develops and transmits information rapidly, they have low reliability. Even though, social media have a high impact on international relations development in the Western Balkan Countires, not everything they report is reliable to the public and institutions.

In the questionnaire respondents have also answered the question of what is the impact of social media on traditional ones.

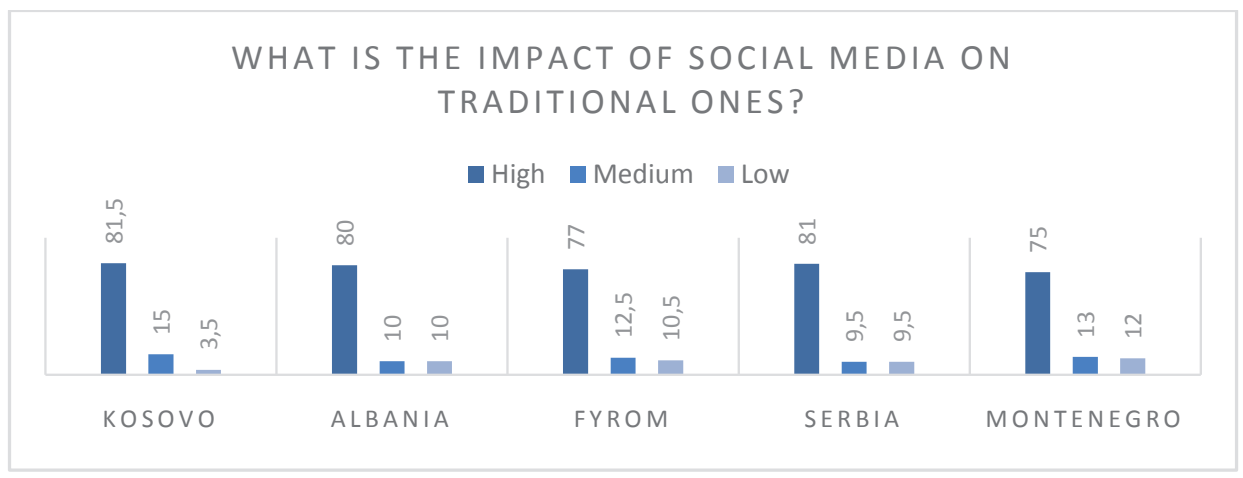

Table 8. The impact of social media on traditional media

In Kosovo $81.5 \%$ and Serbia $81 \%$ of respondents affirmed that social media have a high impact on traditional ones in relation of international relations development. High percentage is in all places where in this question Montenegro reaches least percentage with $75 \%$.

In Kosovo $15 \%$ and in Montenegro $13 \%$ of respondents affirmed that social media have an average impact on traditional ones. Meanwhile $12 \%$ of respondents in Montenegro and $10.5 \%$ in Macedonia (FYROM) consider that social media have low impact on traditional media. This implies that the influence of social media is high in traditional ones, so social media influencing traditional media necessarily influence international policy.

\section{CONCLUSION}

- Social media have direct impact on the change and development of international politics in Western Balkan Countries.

- It is exist a discrepancy between the impact of social networks and their reliability. From the survey, it is noted that on average about $50 \%$ of respondents have a low confidence in social media reporting. This implies that traditional media still have higher reliability in broadcasting information. 
- The use of social media is not considered as reliable, and comlicate free communication.

- From the collected data we also found that most of respondents have considered that public institutions should communicate through social media, reasoning its use by public employees. This because of the high level of internet and technology usage in Western Ballkan Countries.

- The survey also noted that social media has contributed to the increasment of public institutions transparency, directly affecting in easier and faster detection of information. This has increased responsibility for official actions and civic influence in decision-making.

- Social media have more influence than traditional media on state institutions in Western Balkan Countries. The impact of social media is also grows by their influence on traditional media.

- It should be noted that social media are also influenced. Unusual news or events affect the orientation of debates and their development in social media. Also the opinions of public individuals, such as politicians, artists, or famous athletes influence the development of online media.

\section{RECOMMENDATIONS}

After conducting the research, there are issued some recommendations that can help institutions or researchers.

- Because of high impact of social media, it should be conducted researches by adequate staff to increase the reliability of information accuracy;

- Institutions should use this communication opportunity to improve their image. This serves as a way to increase institutional credibility through social media;

- Communication through social media should be used carefully. Their unthinking use may result in great sensitivity;

- Institutions should recruit their staff on the use and functioning of social media, in order to increase the efficiency of use;

- $\quad$ The establishment of a regional body by all Western Balkan Countries, to undertake harmonized legal initiatives, firstly to prevent untrue materials and those that promote racism, nationalism, xenophobia, materials with certain motives and those that are unilaterally reported, and others;

- Social media have changed reports in international relations, but the protocol operation system remains the same. To be taken into consideration the updating laws on state protocols, and other relevant laws. 


\section{REFERENCES}

Albanian Media Institute. (2015). Zhvillimi i internetit dhe mediave sociale në Shqipëri. Tiranë: Albanian Media Institue.

Blic. (2017, 07 25). www.blic.rs. Retrieved from Blic Online: https://www.blic.rs/vesti/ ekonomija/surova-istina-srbi-na-zacelju-liste-balkanskih-zemalja-po-koriscenju-interneta-i/ y5jetf2

Clifton, M., \& Jagla, L. (2013). Integrating Diplomacy and Social Media. Washington, D.C.: The Aspen Institute.

Fox News. (2017, January 26). Retrieved from Fox News: http://www.foxnews.com/ politics/2017/01/26/trump-no-meeting-with-pe-nieto-if-mexico-wont-pay-for-wall.html

Gordon, J. (2010). Use, Value and Impact of Social Media on Public Relations Practitioners in the Fox Cities. University of Wisconsin Oshkosh.

Kosovo Agency of Statistics. (2018). Rezultatet e Anketës së Përdorimit të. Prishtina: Kosovo Agency of Statistics.

Lapsi Al. (2015, 07 10). Retrieved from Lapsi Al: http://lapsi.al/2015/07/10/sherri-vucicrama-ne-twitter-te-gjitha-replikat-pas-vendimit-te-cas/

Mayfield, A. (2008). What is social media? San Francisco, California: Icrossing.

McNair, B. (1998). The sociology of journalism. London, New York, Sydney, Auckland: Arnold.: Oxford University Press.

Nickles, D. P. (2003). Under the Wire. Harvard Historical Studies.

Sheedy, C. S. (2011). Social Media for Social Change: A Case Study of Social Media Use in the 2011 Egyptian Revolution. Capstone Project.

State Statistical Office - RM. (2016). Macedonia in figures. Skopje: State Statistical Office - Republic of Macedonia.

Statistical Office of Montenegro. (2016). ICT usage in Montenegro in 2016. Podgorica: Statistical Office of Montenegro.

Toivo, S. (2012). Social Media - The New Power of Political Influence. Brussels: Center for European Studies. 